\title{
Short communication: The beef merit of the sire mated to a dairy female affects her subsequent performance
}

\author{
D. P. Berry ${ }^{1 *}$ (1) and S. C. Ring ${ }^{2}$ () \\ ${ }^{1}$ Teagasc, Animal and Grassland Research and Innovation Centre, Moorepark, Fermoy P61 P302, Co. Cork, Ireland \\ ${ }^{2}$ Irish Cattle Breeding Federation, Highfield House, Shinagh, Bandon P72 X050, Co. Cork, Ireland
}

\begin{abstract}
Much of the research to date on dairy $\times$ beef matings has focused only on the greater revenue attainable from these beef-cross calves. The objective of the present study was to quantify the mean effect on cow performance following the birth of calves differing in beef merit; all calves were born without calving assistance. Beef merit in the present study was based on the breed of the sire but also its genetic merit for carcass weight and conformation. The cross-sectional study used up to 346,765 calving events from 230,255 Holstein-Friesian cows in 3,604 herds. Performance traits of interest were those associated with milk production, including somatic cell count, as well as female reproductive performance. Sire breed was associated with all yield traits, somatic cell count, and both pregnancy rate and the interval from calving to first service; no association existed with either submission rate or number of services. Relative to a Holstein-Friesian sire, the mean 305-d milk yield (in kg) was 45.22 (standard error, $\mathrm{SE}=4.0), 62.0(\mathrm{SE}=36.8), 65.4(\mathrm{SE}=9.6), 101.1$ $(\mathrm{SE}=31.6), 36.7(\mathrm{SE}=4.9), 51.5(\mathrm{SE}=10.7), 53.3$ $(\mathrm{SE}=31.5)$, and $43.3(\mathrm{SE}=23.4)$ less for cows that gave birth to Angus-, Aubrac-, Beligan Blue-, Charolais-, Hereford-, Limousin-, Saler-, or Simmental-sired calves, respectively. Service sire accounted for only $1 \%$ of the phenotypic variation in all 3 milk production traits when fitted as a random effect in the model. The regression coefficients of phenotypic milk, fat, and protein yields on sire (of calf) predicted transmitting ability for carcass weight were $-1.84(\mathrm{SE}=0.17),-0.10$ $(\mathrm{SE}=0.01)$, and $-0.08 \mathrm{~kg}(\mathrm{SE}=0.01)$, respectively. The respective regression coefficients on sire (of calf) predicted transmitting ability for carcass conformation (scale of 1 to $15 ; 1=$ poor and $15=$ excellent) were $-23.46(\mathrm{SE}=1.81),-1.20(\mathrm{SE}=0.08)$, and -1.05
\end{abstract}

Received March 13, 2020.

Accepted May 18, 2020.

*Corresponding author: donagh.berry@teagasc.ie units $(\mathrm{SE}=0.06)$. The biological significance of the sire breed effects or the measure of sire genetic merit on the reproductive traits was either not different from zero or biologically small. Although statistically significant associations existed between sire beef merit and both milk and reproductive performance of the mate, the actual size of the associations was biologically small. Key words: dairy-beef, milk, fertility, pregnancy

\section{Short Communication}

As a strategy to increase calf value, many dairy producers are increasingly mating beef sires to dairy dams not needed to generate replacements (i.e., either surplus to requirements or genetically inferior). From a price analysis of 53,838 young calves $(<12$ wk of age) born to dairy cows, McHugh et al. (2010) reported a greater value of male calves from beef breeds relative to male calves from dairy breeds. Similarly, based on an analysis of 117,593 carcass records from the progeny of dairy cows, Berry et al. (2018) documented a greater carcass value from Angus $\times$ dairy crosses compared with purebred dairy animals or dairy $\times$ dairy crosses. Additionally, controlled studies have consistently demonstrated superior carcass characteristics from beef $\times$ dairy animals compared with dairy contemporaries (Keane and Drennan, 2008; Campion et al., 2009).

The superior beef merit of beef $x$ dairy calves contributes to greater revenue for dairy producers through greater beef revenue. However, the repercussions of the beef-cross pregnancies on the subsequent performance of the dairy female have not been thoroughly investigated. Beef-sired calves, especially those from Continental breeds, are known to be generally more prone to a difficult calving (Fouz et al., 2013; Eriksson et al., 2020), and the effect of calving dystocia on subsequent dairy cow performance is well established (Dematawena and Berger, 1997; Berry et al., 2007, 2019). However, what has not yet been studied is the effect of beef-sired calves on the subsequent performance of the dairy cow in the absence of any calving dystocia. Isogai et al. (1994) reported no difference in either subsequent lactation milk 
production or reproductive performance among Japanese Holstein cows mated to different breeds of sires, although no account was taken of calving difficulty in that study. Furthermore, the study was relatively small with just 641 cows stratified into 7 breed group types, and thus the statistical power to detect significant differences would have been compromised.

Therefore, the objective of the present study was to quantify the association of sire beef merit with the milk and reproductive performance of his mate in the ensuing lactation in the absence of reported calving difficulty. Beef merit here is represented by both the breed of the sire and the genetic merit of the sire for carcass weight and conformation. This information can help inform decision making and cost-benefit analyses of using different sires and can provide the necessary parameters required for the derivation of economic values, especially in breeding goals that are specific for choosing beef sires for use on dairy females (Berry et al., 2019).

Performance data were available from Holstein-Friesian cows residing in Irish spring-calving dairy herds calving between 2015 and 2019 inclusive. Dystocia in Ireland is voluntarily recorded by cattle producers on a 1-to- 4 scale $(1=$ no assistance; $2=$ assistance provided with some calving difficulty; $3=$ assistance provided with considerable calving difficulty but without veterinary intervention; and $4=$ assistance provided with considerable calving difficulty resulting in veterinary intervention). Only data from herd-years that recorded at least $5 \%$ of their calving events requiring some assistance that year were retained. A total of $1,764,075$ singleton calving events from 896,629 Holstein-Friesian dairy cows residing in 7,353 herds were available. Only herds that participated in routine milk recording were retained, as were lactations initiated by the birth of a calf sired by any one of the breeds Angus, Aubrac, Belgian Blue, Charolais, Hereford, Holstein-Friesian, Limousin, Saler, or Simmental. Both the sire and dam of the calf, as well as both its maternal grand-dam and maternal grand-sire, had to be recorded. Predicted transmitting ability estimates were available for milk yield, fat yield, protein yield, SCC, and both progeny carcass weight and conformation (Pabiou et al., 2011) for the last national genetic evaluation of both the 2014 and 2019 calendar years. The EBV of each cow for milk, fat, and protein yield as well as SCS was calculated as the sum of the respective sire and dam PTA from the 2014 genetic evaluation; none of the phenotypic data used in the present study, therefore, contributed to this genetic evaluation. The PTA of each sire (of calf) from the 2019 national genetic evaluation for both carcass weight and carcass conformation was also retained for later use in the statistical model. Carcass weight is measured in kilograms, whereas carcass conformation score is measured on a 1 -to- 15 scale, where $1=$ poor conformation and $15=$ excellent conformation (Englishby et al., 2016).

Total 305-d lactation milk, fat, and protein yield as well as mean lactation logarithm of SCC to the base 10 (herein known as SCS) were also available. Only calvings that occurred between January and April inclusive were retained, which represents the bulk (i.e., 76\%) of calvings in Irish spring-calving dairy herds (Berry et al., 2013).

Calving dates and service dates, as well as associated pregnancy diagnosis data (where available), were also available on all animals in these herds for the calendar years of 2015 to 2019 inclusive. Four reproductive traits were defined for use in the present study similar to those defined previously in Irish dairy cows by Berry et al. (2013). Calving to first service interval (CFS) was defined as the number of days from calving to first service; CFS records were discarded if $<20$ or $>250 \mathrm{~d}$. Number of services (NSer) was defined as the number of times a cow was served per lactation; lactations with $>10$ services were given a value of 10 . The breeding season was defined for each herd separately and was assumed to have begun when 5 cows were served within $14 \mathrm{~d}$ of the initial service for that herd. Submission rate (SR21) in the present study was defined as whether a cow was served for the first time in the first $21 \mathrm{~d}$ of the breeding season; all cows had to have been at least $35 \mathrm{~d}$ calved by the start of the breeding season to be considered. Pregnant in the first $42 \mathrm{~d}$ of the breeding season (PR42) was as defined by Berry et al. (2013). Only data from breeding seasons where AI was used and the length of the AI breeding season was at least 42 $\mathrm{d}$ were retained. Cows that had a recorded service date (either artificial or natural) after d 42 of the breeding season were coded as not PR42. For cows that still had no information for PR42, those served within 30 $\mathrm{d}$ of either the end of the breeding season or before being sold were coded as missing unless they had an empty pregnancy diagnosis recorded after being served $42 \mathrm{~d}$ after the start of the breeding season. Otherwise, where they had a subsequent calving date confirming, based on the calculated gestation length, that they were pregnant in the first $42 \mathrm{~d}$ of the breeding season, they were assumed pregnant. Where subsequent calving dates were not available, pregnancy diagnosis data were also used to further attempt to determine whether the cow was pregnant in the first $42 \mathrm{~d}$ of the breeding season. Where no subsequent calving date was available and the cow had no recorded service after $42 \mathrm{~d}$ of the breeding season but was diagnosed as being pregnant, 
then the cow was deemed to have become pregnant in the first $42 \mathrm{~d}$.

Contemporary groups of herd-year-season of calving were defined for all traits using an algorithm routinely used in Irish national genetic evaluations (Berry et al., 2013; McHugh et al., 2014). A maximum of 30-d duration was allowed for each contemporary group, and each contemporary group had to have at least 5 records. The final edit imposed was that each contemporary group had to have progeny from at least 2 sires of at least 2 breeds. A separate data set was generated for just Holstein-Friesian sires where an edit was imposed that contemporary groups (with $\geq 5$ records) had to have at least 3 Holstein-Friesian sires used. Following all edits, milk production (including SCS) data from a total of 339,875 lactations were available when all breeds were considered and 346,765 lactations when based on the Holstein-Friesian data set; the respective numbers for the reproductive traits were 248,881 and 271,267. Based on the multibreed milk production data set, a total of 13,870 sires were represented with, on average, 51 progeny per sire. The number of Angus, Aubrac, Belgian Blue, Charolais, Hereford, Holstein-Friesian, Limousin, Saler, and Simmental sires was 4,200, 71, $159,131,2,062,6,334,632,85$, and 196, respectively.

The association between either sire (of the calf) breed or sire PTA and mate performance traits was estimated using linear (continuous traits) or logistic (binary traits) mixed models in AsReml (Gilmour et al., 2009); cow was included as a random effect in all models. Nuisance fixed effects included in all models were the parity of the cow $(1,2,3+)$, calf sex, heterosis coefficient of the cow, and contemporary group; heterosis was included to capture the known heterosis effect between Holstein and Friesians that make up the Holstein-Friesian (Coffey et al., 2016). Sire (of calf) breed was also included as a class variable in one set of analyses, and this was replaced by a covariate for sire PTA for either carcass weight or carcass conformation in a second set of analyses. In all models relating to milk production (including SCS), the dam's EBV for the trait represented by the dependent variable was also included in the model. For the analyses of the reproductive traits, the number of days from calving to the start of the herd's breeding season was also fitted as a covariate. In a separate series of analyses, the fixed effect representing sire breed or genetic merit was replaced by a random sire (of the calf) effect and the variance components estimated as $N \sim\left(0, \mathbf{I} \sigma_{\text {sire }}^{2}\right)$, where $\sigma_{\text {sire }}^{2}$ is the sire variance and $\mathbf{I}$ is an identity matrix.

Mean milk, fat, and protein yield of the edited data set were 6,691 $(\mathrm{SD}=1,201), 276.1(\mathrm{SD}=50.9)$, and

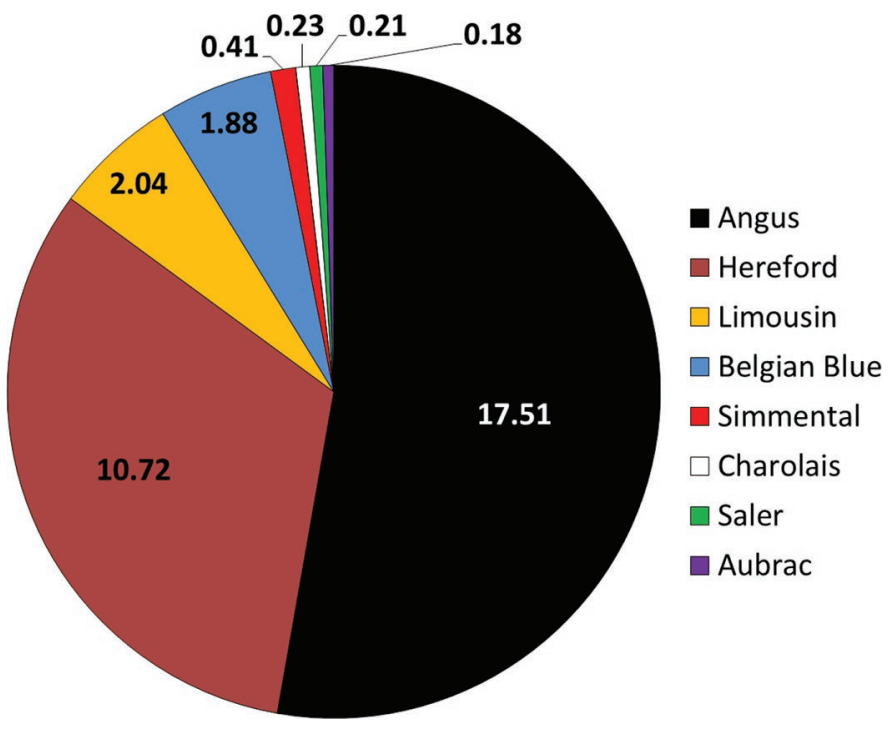

Figure 1. Percentage of the different breeds of sire beef matings in the edited data set.

$239.1 \mathrm{~kg}(\mathrm{SD}=41.7)$, respectively. The mean milk yield in parity 1,2 , and $3+$ animals was $5,483(\mathrm{SE}=7.7)$, $6,466(\mathrm{SE}=7.5)$, and $7,077 \mathrm{~kg}(\mathrm{SE}=7.24)$, respectively, implying that a mature cow yielded $29 \%$ more than a first-parity cow; the respective values for fat and protein yield between first-parity and mature cows were 27 and $30 \%$, respectively. The mean CFS and NSer were $77 \mathrm{~d}(\mathrm{SD}=23.6)$ and 1.37 units $(\mathrm{SD}=0.66)$, respectively. The mean SR21 and PR42 were 0.84 and 0.59 , respectively. Figure 1 represents each beef breed of sire in the data set of milk-recorded spring-calving cows; $67 \%$ of all matings were to Holstein-Friesian sires with 17.5 and $10.7 \%$ of total matings to Angus and Hereford sires, respectively, representing 53 and $32 \%$ of the beef sire matings (Figure 1).

The mean milk, fat, and protein yield from dams that gave birth to a male calf were $12.71(\mathrm{SE}=2.3)$, $0.15(\mathrm{SE}=0.10)$, and $0.23 \mathrm{~kg}(\mathrm{SE}=0.08)$ greater, respectively, than those that gave birth to female calves; like fat yield, calf sex was not associated with SCS. Of the 4 reproductive traits investigated in the present study, calf sex was associated only with CFS, which was just $0.16 \mathrm{~d}(\mathrm{SE}=0.05)$ longer following the birth of a female calf; this association is biologically miniscule. Several studies in dairy cattle have reported associations between calf sex and milk production (Hinde et al., 2014; Graesboll et al., 2015; Hess et al., 2016), although none, to our knowledge, have investigated the association with either SCS or reproductive performance. Previously reported associations between calf sex and subsequent milk production in dairy cows 
are inconsistent (summarized by Hess et al., 2016); however, there is a general tendency for higher production in cows that had just given birth to a heifer calf, although the model solutions differ by parity (Hess et al., 2016). Whereas calf sex was not associated with fat yield in the present study, both 305-d milk and protein yield were slightly increased (i.e., $<0.2 \%$ relative to the population mean) following the birth of a male calf. Nonetheless, a small sex effect is consistent with previous studies (for summary see Hess et al., 2016), the exception being the study of Hinde et al. (2014) in US Holsteins, where a $2.7 \%$ greater milk yield was associated with the birth of a female calf. The biological rationale for an association between calf sex and milk yield of the dam lies in the ability of fetal hormones to cross the placenta, meaning that differences in the levels of hormones affecting lactogenesis may therefore influence milk yield. Hormones such as insulin-like peptide 3 have been shown to be differentially expressed in both the dam and the fetus depending on whether the fetus was male of female (Adham et al., 2002).

The regression coefficient of phenotypic milk, fat, and protein yields on the respective EBV of the cow for that trait was $1.05(0.01), 1.0(0.01)$ and $0.96(0.01)$, respectively. This is in line with the expectation of 1 for the regression of phenotype on its EBV, and similar results have been documented for milk yield in Irish dairy cows (Dunne et al., 2019). The inclusion of this covariate in the model was an attempt to mitigate against any assortative mating bias of low-yielding cows being mated to beef bulls. Using Irish data, Berry and Ring (2020) reported that milk solids yield in the previous lactation was associated with the likelihood of a dairy cow being mated to a beef bull versus being mated to a dairy bull. One hundred percent heterosis was associated with $155.6(\mathrm{SE}=7.9), 5.24(\mathrm{SE}=0.33)$, and $5.1 \mathrm{~kg}(\mathrm{SE}=$ $0.26)$ more milk, fat, and protein yields, respectively. Superior milk performance of crossbred animals has been reported previously even between Holsteins and Friesians (Harris and Kolver, 2001; Coffey et al., 2016). The observed favorable effect of dam heterosis in the present study on reproductive performance, although not always significant, is also consistent with that reported elsewhere among the Holstein and Friesian breeds (Harris and Kolver, 2001; Coffey et al., 2016). For example, the predict probability of PR42 was 5 percentage units greater for an $\mathrm{F}_{1}$ crossbred HolsteinFriesian cow versus a purebred cow of either breed with a $95 \%$ confidence interval stretch of 4 percentage units on either side of the mean.

Sire breed was associated $(P<0.001)$ with milk, fat, and protein yield and SCS; the least squares means for the yield traits by each sire breed are given in Figure 2. Relative to a Holstein-Friesian sire, the mean 305-d milk yield (in $\mathrm{kg})$ was $45.22(\mathrm{SE}=4.0), 62.0(\mathrm{SE}=$ $36.8), 65.4(\mathrm{SE}=9.6), 101.1(\mathrm{SE}=31.6), 36.7(\mathrm{SE}=$ $4.9), 51.5(\mathrm{SE}=10.7), 53.3(\mathrm{SE}=31.5)$, and $43.3(\mathrm{SE}$ = 23.4) less for Angus-, Aubrac-, Belgian Blue-, Charolais-, Hereford-, Limousin-, Saler-, and Simmental-sired calves, respectively. These breed effects represent up to only a $1.5 \%$ loss in yield when using a beef sire relative to when using a Holstein-Friesian sire. The SCS least squares means (in $\log _{10}$ units) for dams mated to an Angus, Aubrac, Belgian Blue, Charolais, Hereford, Holstein-Friesian, Limousin, Saler, or Simmental sire were $4.83(\mathrm{SE}=0.002), 4.74(\mathrm{SE}=0.019), 4.86(\mathrm{SE}$ $=0.005), 4.86(\mathrm{SE}=0.014), 4.83(\mathrm{SE}=0.002), 4.83$ $(\mathrm{SE}=0.001), 4.82(\mathrm{SE}=0.005), 4.84(\mathrm{SE}=0.014)$, and $4.89(\mathrm{SE}=0.010)$, respectively. Cow accounted for $25,48,54$, and $33 \%$ of the phenotypic variance in milk, fat, and protein yield and SCS, respectively, and sire of the calf included as a random effect accounted for $\leq 1 \%$ of the phenotypic variance for all traits, although the inclusion of sire as a random effect in the models did improve $(P<0.001)$ the fit to the data. The large contribution of the cow to the phenotypic differences in the yield traits is similar to what has been reported for the repeatability of these yield parameters (0.66 to 0.72 ; Berry et al., 2003). The lack of a (large) contribution of the sire of the calf to the variability in the 4 milk production traits suggests minimal effect. The contribution of calf sire to the total phenotypic variance in lactation yield among Holstein (Johnson and Van Vleck, 1979) and Jersey (Moya et al., 1989) cows has previously been reported to vary from 0.4 to $3.8 \%$. No study has previously investigated the effect of sire of calf on the SCS of his mate, but results from the present study suggest a stress associated with the birth of most beef-cross calves as evidenced by a greater SCS. All in all, the effect of considering the sire of the calf born in genetic evaluations for lactation performance is expected to be small.

When applied across all sire breeds, the regression coefficients of phenotypic milk, fat, and protein yield on sire (of calf) PTA for carcass weight were -1.84 (SE $=0.17),-0.10(\mathrm{SE}=0.01)$, and $-0.08 \mathrm{~kg}(\mathrm{SE}=0.01)$, respectively. The regression coefficients of phenotypic milk, fat, and protein yield on sire PTA for carcass conformation (scale of 1 to 15 , where $1=$ poor and $15=$ excellent) were $-23.46(\mathrm{SE}=1.81),-1.20(\mathrm{SE}=0.08)$, and -1.05 units $(\mathrm{SE}=0.06)$, respectively. The regression coefficient of SCS on sire PTA for carcass weight and conformation was $0.0006(\mathrm{SE}=0.00009)$ and 0.004 $\log _{10}$ units $(\mathrm{SE}=0.0009)$, respectively. When the analyses were restricted to just Holstein-Friesian sires, no association existed between sire PTA for either carcass weight or conformation and any of the milk production traits. When the Holstein-Friesian sires were stratified 
into 4 groups on PTA for carcass conformation, no association with the milk production traits was detected, but an association was detected between sire stratum for PTA of carcass weight and all 3 of the yield traits. Relative to the heaviest PTA carcass weight stratum, dairy cows mated to the Holstein-Friesian sires with the lightest PTA for carcass weight yielded $12.38 \mathrm{~kg}(\mathrm{SE}=$ 4.19) more milk, $0.59 \mathrm{~kg}(\mathrm{SE}=0.19)$ more fat, and 0.41 $\mathrm{kg}(\mathrm{SE}=0.14)$ more protein; these represent $<0.2 \%$ of the mean total lactation yield, making it biologically insignificant and not even equivalent to the yield on a given day in early to mid lactation. Regardless, the mean lactation yield associated with the birth of a Holstein-Friesian-sired calf in the heaviest quartile for PTA for carcass weight was still greater than the mean yield when the calf was sired by a beef bull. In an analysis of 1,471 calving events from US Holstein cows, Chew et al. (1981) reported a positive association between calf birth weight (between 23 and $50 \mathrm{~kg}$ ) and 200-d yield; however, their study did not take into account the size of the cow. Given that live weight across ages (including mature cows) in cattle is correlated (McHugh et al., 2011) and that cows that yield more tend to be larger (Berry et al., 2004), the observed positive trends between calf birth weight and cow yield may simply be a manifestation of the underlying genetic correlation structure between calf birth weight, cow mature size, and lactation yield. To circumvent this shortcoming (where actual cow live-weight data were not available), the present study included sire genetic merit for carcass weight as a covariate in the model; no genetic evaluations for birth weight were available. The results from the present study are, nonetheless, contrary to expectation based on evolutionary biology. Following the hypothesis of Trivers and Willard (1973), dams invest more in reproductively stable offspring, thereby ensuring a continuation of their genetic line. Therefore, maternal investment via increased milk production would be, on average, more warranted in larger calves that are more likely to succeed in any mating competition. Nonetheless, it is likely that the greater maternal (energetic) investment in the last trimester of growth of larger fetuses may have repercussions on subsequent yield.

The weighted mean sire PTA for carcass weight of the more populous Angus, Hereford, Holstein, and Limousin sires in the present study was $1.75,1.70,-5.22$, and $20.08 \mathrm{~kg}$, respectively; the respective values for carcass conformation were $0.64,0.49,-0.68$, and 2.04 units. The breed weighted mean PTA for carcass weight and the estimated regression coefficient of milk production on PTA for carcass weight did not fully match the estimated mean breed effects on milk yield in the present study, implying that the observed breed effects may be more than just attributable to differences in birth weight (approximated by carcass weight). However, the

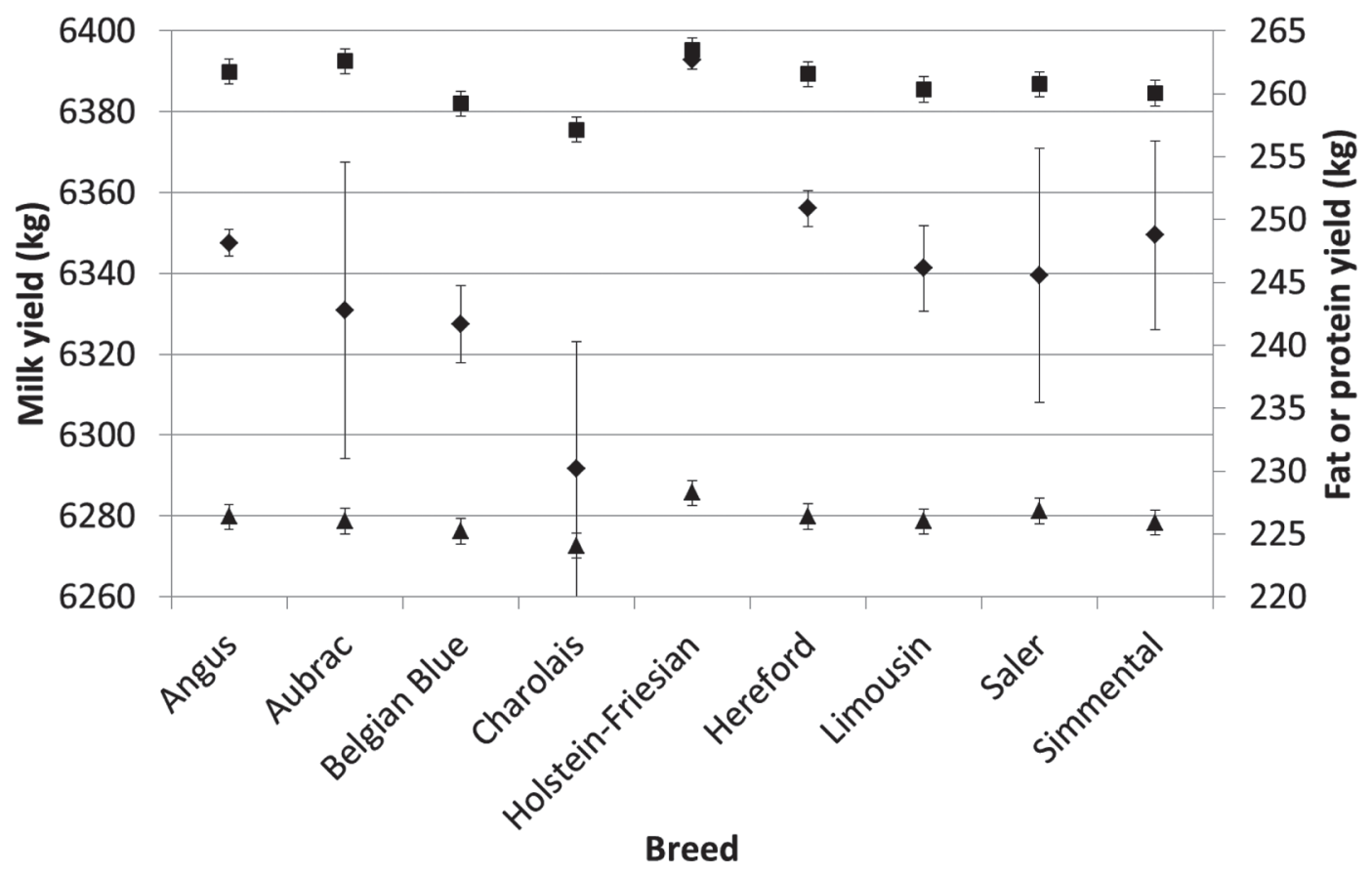

Figure 2. Least squares means $( \pm 1 \mathrm{SE})$ for milk yield $(\bullet)$, fat yield $(\mathbf{\square})$, and protein yield $(\boldsymbol{\Lambda})$ for each breed of sire of calf. 
breed weighted mean PTA for carcass conformation and the estimated regression coefficient of milk production on PTA for carcass conformation more closely aligned with the interbreed differences on the effect on milk yield; this suggests that the observed breed effects on milk production may be somewhat attributable to calf conformation. Using the equation for calculating the net energy requirement for gestation in Holstein cattle (NRC, 2001), the total energy requirement for a $45-\mathrm{kg}$ calf (assumed in NRC, 2001 to be the average birth weight of a Holstein calf) for the last $6 \mathrm{wk}$ of gestation was calculated to be $151.6 \mathrm{Mcal}$ (i.e., $634.3 \mathrm{MJ}$ ). It is assumed here that a $1-\mathrm{kg}$ difference in sire PTA for carcass weight equates to probably a $0.5-\mathrm{kg}$ difference in birth weight after accounting for the relative difference in variance between the birth weight of a calf and the carcass weight of a 2-yr-old animal. Therefore, the expected energy requirement for the last $6 \mathrm{wk}$ of gestation for a calf sired by a Limousin would be $34 \%$ more than for a calf sired by a Holstein. This increased energy demand could be one reason why subsequent yield is low in cows that give birth to heavier calves (here approximated by sire PTA for carcass weight). This suggests a potential to tailor the diet (i.e., quality and quantity) in late lactation and the dry period depending on the sire (breed) of the calf in utero and warrants further investigation. In sheep, for example, many subflocks are managed and fed differently based on their expected litter size when pregnancy is diagnosed.

Moreover, adjusting for differences in sire PTA for carcass weight in the multiple regression model (simultaneous with a sire breed effect) did not influence the significance of the sire breed association with milk yield. Adjusting for differences in sire PTA for carcass conformation, however, resulted in sire breed no longer being associated with milk yield. This is consistent with the mathematics already described where the regression coefficient of milk yield on sire PTA for carcass conformation times the mean PTA per breed closely aligned with the estimated breed effects on dam milk yield. Such a conclusion suggests that the effect of sire breed on the milk yield of the mate is via the conformation (or some correlated feature such as calf protein content) of the resulting crossbred calf. Carcass conformation, which is the variable used in the generation of national genetic evaluations for carcass conformation, reflects a proxy for muscularity and the development of the carcass with a particular emphasis on the round, back, and shoulders. How carcass conformation influences cow yield is not known, but it may be related to the energetic cost during gestation of producing an animal with greater muscle mass and potentially to any stress encountered during the birthing process and its effect on milk yield. Although only lactations initiated by a calving event recorded as not requiring assistance were used in the present study, the method of recording calving difficulty or stress is relatively crude and subjective. Differences in cow stress levels are likely to exist even when no calving assistance was required, but in fact a difficult or prolonged calving may have occurred that could have gone unrecognized by the farmer, and such events could be more frequent for more muscular calves.

Because a standardized 305-d yield was used in the present study and many producers operating seasonal calving systems adopt a dry-off date based on calendar date, the effect of gestation length of beef-cross versus purebred dairy calves was not captured. From a model that included sire (of calf) breed, calf sex, and cow parity, the least squares means gestation length of the most populous breeds of Angus, Hereford, Holstein-Friesian, and Limousin was 283.1 ( $\mathrm{SE}=0.19), 284.7(\mathrm{SE}=$ $0.07), 280.7(\mathrm{SE}=0.04)$, and $286.9 \mathrm{~d}(\mathrm{SE}=0.10)$, respectively. This is not necessarily reflective of the breed average gestation length because dairy farmers actively seek sires that are genetically short for gestation length (Berry and Ring, 2020). Nonetheless, if later calving cows do in fact have a shorter lactation (without any effect on lactation profile), the effect of a beef sire on lactation cow yield could actually be more relative to what was estimated in the present study. The effect of a longer expected gestation length for bulls of different breeds is usually already captured within economic values in total merit indexes (Berry et al., 2019).

Of the 4 reproductive traits investigated, sire breed was associated only $(P<0.001)$ with both CFS and PR42. The least squares means for CFS following the birth of different breed beef sires varied from 64 to $70 \mathrm{~d}$ (Angus $=65.7 \mathrm{~d}, \mathrm{SE}=0.08 \mathrm{~d} ;$ Aubrac $=63.9 \mathrm{~d}, \mathrm{SE}=$ $0.93 \mathrm{~d}$; Belgian Blue $=70.4 \mathrm{~d}, \mathrm{SE}=0.26 \mathrm{~d}$; Charolais $=68.3 \mathrm{~d}, \mathrm{SE}=0.93 \mathrm{~d}$; Hereford $=64.2 \mathrm{~d}, \mathrm{SE}=0.12$ $\mathrm{d}$; Limousin $=64.8 \mathrm{~d}, \mathrm{SE}=0.29 \mathrm{~d}$; Saler $=66.1 \mathrm{~d}, \mathrm{SE}$ $=0.84 \mathrm{~d}$; and Simmental $=66.7 \mathrm{~d}, \mathrm{SE}=0.67 \mathrm{~d}$ ), with the mean CFS following the birth of a Holstein-sired calf being $81.7 \mathrm{~d}(\mathrm{SE}=0.05)$. The predicted probability of PR42 following the birth of a Holstein-sired calf was 0.66. The PR42 for Angus, Aubrac, Belgian Blue, Charolais, Hereford, Limousin, Saler, and Simmental was $0.57,0.55,0.50,0.42,0.55,0.57,0.51$, and 0.58 , respectively; PR42 following the birth of a Charolais cross calf was worse $(P<0.05)$ than that following the birth of all other breeds of calves except the Belgian Blue and Saler. In an analysis of 481 Japanese Holstein dams, Isogai et al. (1994) also failed to detect an association between calf breed and subsequent number of services or days open in the dam; no account was taken 
of calving difficulty in that study. Including sire as a random effect in the model within the present study improved the fit to the data for only CFS; sire of calf explained $5 \%$ of the phenotypic variance in CFS.

When analyzed across breeds, sire PTA for carcass weight was associated with CFS, NSer, and PR42; each 1-kg increase in sire PTA was associated with a 0.04-d $(\mathrm{SE}=0.003)$ shorter CFS, $0.0006(\mathrm{SE}=0.0002)$ more services, and a 0.00098 -unit $(\mathrm{SE}=0.0002)$ reduction in the logit of the probability of PR42. Sire PTA for carcass conformation was also associated with CFS, NSer, and PR42; when all breeds were considered, each 1-unit increase in carcass conformation score (scale of 1 to 15 , where $1=$ poor and $15=$ excellent) was associated with a $0.71-\mathrm{d}(\mathrm{SE}=0.04)$ shorter interval to first service, which decreased to a 0.33 -d $(\mathrm{SE}=0.10)$ shorter interval when limited to just Holstein-Friesian-sired calves. Similarly, each 1-unit increase in sire PTA for carcass conformation score was associated with 0.005 ( $\mathrm{SE}=$ 0.002) extra services and a reduction in the logit of the probability of PR42 of 0.01 ( $\mathrm{SE}=0.002)$, all of which did not differ from zero once confined to the HolsteinFriesian population. Therefore, the effect of sire genetic merit on the reproductive performance of his mate is expected to be biologically negligible.

The use of beef sires on dairy females is increasing in popularity in many countries as the reproductive performance of the dairy herd improves (Berry et al., 2014) coupled with herd sizes on individual farm blocks reaching their stocking capacity. Furthermore, diversifying the sources of revenue (i.e., beef vs. dairy) can be extremely beneficial in maintaining resilience in the presence of market volatility for both commodities. Mating with beef sires in Ireland tends to happen toward the latter part of the breeding season (Berry et al., 2020) when sufficient replacement females are likely to have been reached but also because the fertility of some beef breeds (e.g., Hereford) is superior to that of dairy breeds (Berry et al., 2011), a characteristic that is important at the end of the breeding season. Mating dairy females with beef sires also results in heterosis of the embryo, which is likely to affect viability. The rationale for such dairy-beef mating strategies is that the superior carcass weight (Clarke et al., 2009), conformation (Clarke et al., 2009), and primal cut weights (Judge et al., 2019) of beef breeds translate to greater calf price (McHugh et al., 2010).

The proportion of matings recorded nationally in Ireland between beef sires and Holstein-Friesian dams is shown in Figure 3. Fitting a linear regression through the data from the 2011 calendar year, the proportion of matings to beef sires is increasing by 0.022 per year, and the proportion of matings to Angus sires is increas- ing by 0.013 annually. To aid in the decision making of beef sire selection for this growing market, Berry et al. (2019) proposed the use of what they termed a dairy-beef index to rank beef sires on expected profit from their resulting calves. In their dairy-beef index, Berry et al. (2019) included both the cost of production traits and revenue-related characteristics of the sire. The former included the effect of both calving difficulty and gestation length on the economic performance of the cow. Not considered in that index, however, was any possible additional effect of the beef mating on the performance of the cow herself, even in the absence of calving assistance being required (i.e., thus avoiding double counting). Results from the present study indicate that, in fact, lactation yield is lower when the calf born is sired by a beef sire relative to a dairy sire. Assuming a milk price of 30.5 cents/L (Berry et al., 2019), the effect of the reduced lactation yield equates to an opportunity cost of $€ 11.19$ to $€ 30.84$ if mated to a beef sire. This of course would not necessarily translate into an equitable loss in profit because such cows are also expected to eat less. Moreover, if the association is proportional to yield, then the economic impact could be greater in higher yielding cows, and, in many instances, the cost might equate to a considerable proportion of the extra value from having the superior beef calf in the first place. Therefore, such an effect may justify consideration within total merit indexes for sire selection. Based on the economic weight for calving difficulty in multiparous cows reported by Berry et al. (2019) for the construction of a dairy-beef index, coupled with the mean PTA of the top sires per breed ranked on a dairy-beef index (Berry et al., 2019), the economic consequences for reduced milk yield following the mating to individual breeds were actually similar in magnitude to the expected monetary cost based on the other effects described by Berry et al. (2019). The exception was the Angus breed, which had a superior PTA for direct calving difficulty in multiparous cows compared with that of the Holstein-Friesian breed. This therefore indicates that this monetary cost on cow milk performance should be accounted for in any index that ranks beef (and dairy) bulls for use on dairy females.

Given the association between sire and performance of his mate, consideration of the sire (of the calf) in national genetic evaluations for milk yield may warrant further investigation. In the present study at least, sire accounted for only $<1 \%$ of the phenotypic variance in the milk production traits. However, it should be remembered that, with the quoted heritability of 2 to $3 \%$ for fertility (Berry et al., 2014), considerable emphasis is placed on these traits within breeding goals despite difference in breeding values representing just 
a small proportion of the phenotypic variance. In fact, the standard deviation for the sire effect on milk yield was $80.16 \mathrm{~kg}$ in the present study.

Of particular note in the present study was that the calves born from beef sires were only $50 \%$ beef. With advancements in in vitro embryo production (Boni, 2012; Morotti et al., 2014), there is a possibility of replacing (some) AI with beef semen with actual implantation of embryos. In these situations, the embryos implanted could be purebred beef animals, thus reaping the benefit of beef carcass economic merit versus beef $\times$ dairy cross carcasses (Clarke et al., 2009); however, studies to date comparing both genotypes have generally been confounded with production system. It is unknown whether the quantified effects of calf breed on cow performance observed in the present can be doubled if the beef calf is purebred as opposed to crossbred. This assumption does, however, seem logical because based solely on additive genetic merit, the carcass conformation EBV of the purebred calf has the potential to be twice the EBV for carcass conformation of the crossbred dairy $\times$ beef calf.

Results from the present study demonstrate that the sire of the calf influences subsequent milk and reproductive performance of the dam, even in the absence of any assistance being required at calving. Beef sires, from some breeds at least, are, on average, more predisposed to requiring assistance at birth (Fouz et al., 2013), thus compounding the effects observed in the present study (Dematawena and Berger, 1997; Berry et al., 2007, 2019). Nonetheless, although differences exist among breeds in mean risk of calving difficulty, considerable within-breed variability in genetic merit for direct calving difficulty (and gestation length) exists (Berry and Ring, 2020). Moreover, several more beef breeds exist than investigated in the present study due to a lack of such matings. Charolais cattle, for example, tend to have more muscular carcasses (Albertí et al., 2008), and given the association between carcass conformation of the calf's sire and the milk performance of the mate, the actual extreme of the breed effects could be larger than detected in the present study. Nevertheless, it is the role of breeding goals, such as those proposed by Berry et al. (2019), to identify beef sires suitable for use on dairy females, thus reducing the risk of calving difficulty without necessarily compromising carcass merit. Moreover, considerable within-breed variability exists in PTA for carcass weight and conformation (Berry and Ring, 2020), implying that genetic change in these traits is possible. Although statistically significant effects on dam performance were identified, the actual effects are biologically small. Nonetheless, the monetary cost of loss in milk production from using alternative breeds of beef bulls (in the absence of calving difficulty) is often similar in magnitude to the combined monetary costs of more difficult calvings. Therefore, not considering

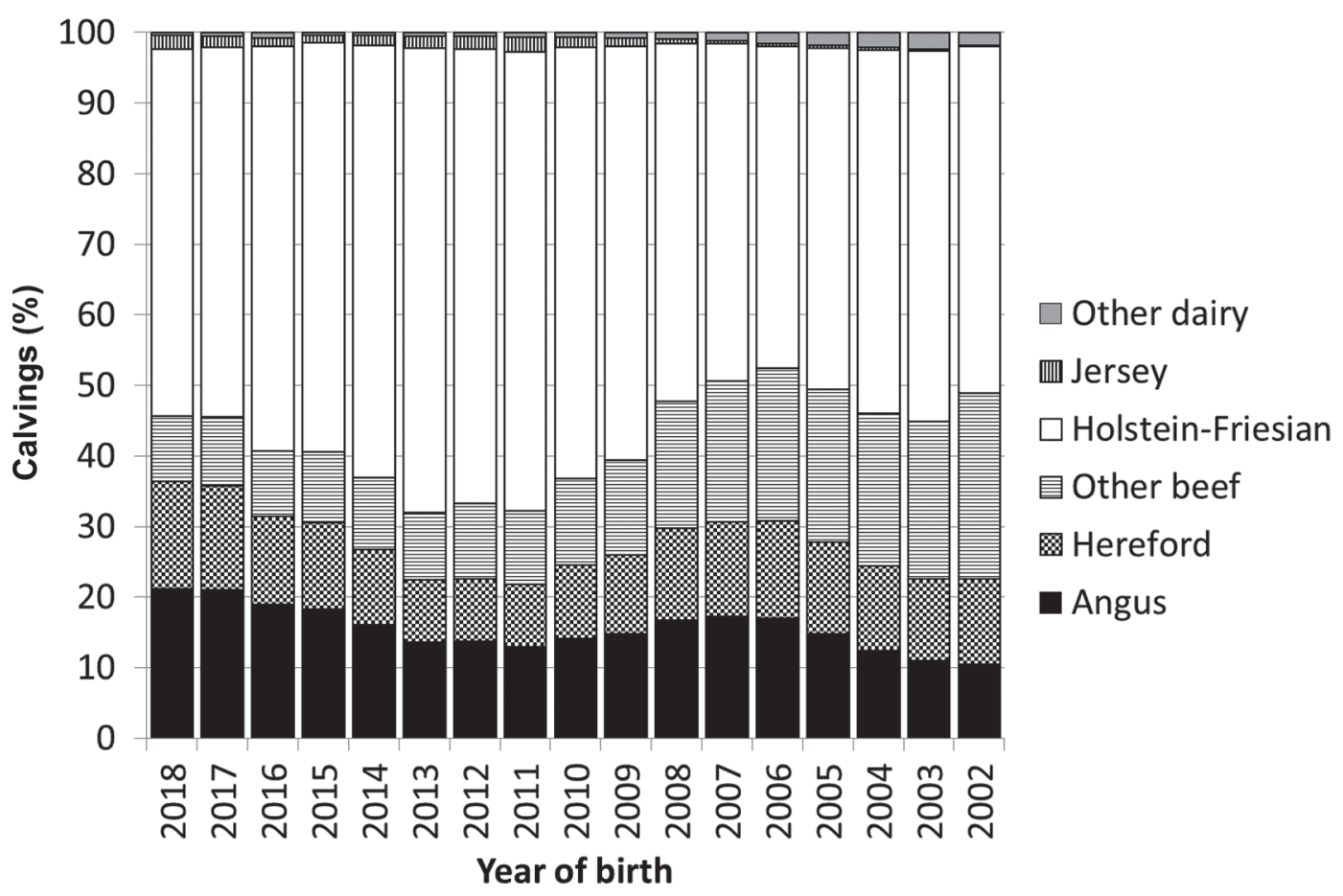

Figure 3. Representation of sire breeds by year of birth to Irish Holstein-Friesian dams in Ireland. 
these mean losses in performance within breeding goals could contribute to an underestimation of the economic repercussions of using different bulls.

\section{ACKNOWLEDGMENTS}

This publication originated from research supported by a research grant from Science Foundation Ireland and the Department of Agriculture, Food and Marine (Dublin, Ireland) on behalf of the Government of Ireland under Grant 16/RC/3835 (VistaMilk) as well as the Research Stimulus Fund Dairy4Beef. The authors have not stated any conflicts of interest.

\section{REFERENCES}

Adham, I. M., G. Steding, T. Thamm, E. E. Büllesbach, C. Schwabe, I. Paprotta, and W. Engel. 2002. The overexpression of the insl3 in female mice causes descent of the ovaries. Mol. Endocrinol. 16:244-252. https://doi.org/10.1210/mend.16.2.0772.

Albertí, P., B. Panea, C. Sañudo, J. L. Olleta, G. Ripoll, P. Ertbjerg, M. Christensen, S. Gigli, S. Failla, S. Concetti, J. F. Hocquette, R. Jailler, S. Rudel, G. Renand, G. R. Nute, R. I. Richardson, and J. L. Williams. 2008. Live weight, body size and carcass characteristics of young bulls of fifteen European breeds. Livest. Sci. 114:19-30. https://doi.org/10.1016/j.livsci.2007.04.010.

Berry, D. P., P. R. Amer, R. D. Evans, T. Byrne, A. R. Cromie, and F. Hely. 2019. A breeding index to rank beef bulls for use on dairy females to maximize profit. J. Dairy Sci. 102:10056-10072. https:/ /doi.org/10.3168/jds.2019-16912.

Berry, D. P., F. Buckley, P. G. Dillon, R. D. Evans, M. Rath, and R. F. Veerkamp. 2003. Genetic relationships among body condition score, body weight, milk yield and fertility in dairy cows. J. Dairy Sci. 86:2193-2204. https://doi.org/10.3168/jds.S0022 -0302(03) 73809-0.

Berry, D. P., F. Buckley, P. G. Dillon, R. D. Evans, and R. F. Veerkamp. 2004. Genetic relationships among linear type traits, milk yield, body weight, fertility and somatic cell count in primiparous dairy cows. Ir. J. Agric. Food Res. 43:161-176.

Berry, D. P., R. D. Evans, and S. McParland. 2011. Evaluation of bull fertility in dairy and beef cattle using cow field data. Theriogenology 75:172-181. https://doi.org/10.1016/j.theriogenology.2010.08 .002 .

Berry, D. P., M. J. Judge, R. D. Evans, F. Buckley, and A. R. Cromie. 2018. Carcass characteristics of cattle differing in Jersey proportion. J. Dairy Sci. 101:11052-11060. https://doi.org/10.3168/jds .2018-14992.

Berry, D. P., J. F. Kearney, K. Twomey, and R. D. Evans. 2013. Genetics of reproductive performance in seasonal calving dairy cattle production systems. Ir. J. Agric. Food Res. 52:1-16.

Berry, D. P., J. M. Lee, K. A. Macdonald, and J. R. Roche. 2007. Body condition score and body weight effects on dystocia and stillbirths and consequent effects on post-calving performance. J. Dairy Sci. 90:4201-4211. https://doi.org/10.3168/jds.2007-0023.

Berry, D. P., and S. C. Ring. 2020. Observed progeny performance validates the benefit of mating genetically elite beef sires to dairy females. J. Dairy Sci. 103:2523-2533. https://doi.org/10.3168/jds 2019-17431.

Berry, D. P., S. C. Ring, A. J. Twomey, and R. D. Evans. 2020. Choice of artificial insemination beef bulls used to mate with female dairy cattle. J. Dairy Sci. 103:1701-1710. https://doi.org/10.3168/jds .2019-17430.

Berry, D. P., E. Wall, and J. E. Pryce. 2014. Genetics and genomic of reproductive performances in dairy and beef cattle. Animal 8(Suppl. 1):105-121. https://doi.org/10.1017/S1751731114000743.
Boni, R. 2012. Ovum pick-up in cattle: A 25 yr retrospective analysis. Anim. Reprod. 9:362-369.

Campion, B., M. G. Keane, D. A. Kenny, and D. P. Berry. 2009. Evaluation of estimated genetic merit for carcass weight in beef cattle: Live weights, feed intake, body measurements, skeletal and muscular scores, and carcass characteristics. Livest. Sci. 126:87-99.

Chew, B. P., L. C. Maier, J. K. Hillers, and A. S. Hodgson. 1981. Relationship between calf birth weight and dam's subsequent 200- and 305-day yields of milk, fat and total solids in Holsteins. J. Dairy Sci. 64:2401-2408. https://doi.org/10.3168/jds.S0022 -0302(81)82863-9.

Clarke, A. M., M. J. Drennan, M. McGee, D. A. Kenny, R. D. Evans, and D. P. Berry. 2009. Intake, live animal scores/measurements and carcass composition and value of late-maturing beef and dairy breeds. Livest. Sci. 126:57-68. https://doi.org/10.1016/j.livsci .2009.05.017.

Coffey, E. L., B. Horan, R. D. Evans, and D. P. Berry. 2016. Milk production and fertility performance of Holstein, Friesian, and Jersey purebred cows and their respective crosses in seasonal-calving commercial farms. J. Dairy Sci. 99:5681-5689. https://doi.org/10 .3168/jds.2015-10530.

Dematawena, C. M. B., and P. J. Berger. 1997. Effect of dystocia on yield, fertility, and cow losses and an economic evaluation of dystocia scores for Holsteins. J. Dairy Sci. 80:754-761. https://doi.org/ 10.3168/jds.S0022-0302(97)75995-2.

Dunne, F. L., S. McParland, M. M. Kelleher, S. W. Walsh, and D. P. Berry. 2019. How herd best linear unbiased estimates affect the progress achievable from gains in additive and nonadditive genetic merit. J. Dairy Sci. 102:5295-5304. https://doi.org/10.3168/jds .2018-16119.

Englishby, T. M., G. Banos, K. L. Moore, M. P. Coffey, R. D. Evans, and D. P. Berry. 2016. Genetic analysis of carcass traits in beef cattle using random regression models. J. Anim. Sci. 94:1354-1364. https://doi.org/10.2527/jas.2015-0246.

Eriksson, S., P. Ask-Gullstrand, W. F. Fikse, E. Jonsson, J.-A. Eriksson, H. Stålhammar, A. Wallenbeck, and A. Hessle. 2020. Different beef breed sires used for crossbreeding with Swedish dairy cows-Effects on calving performance and carcass traits. Livest. Sci. 232:103902. https://doi.org/10.1016/j.livsci.2019.103902.

Fouz, R., F. Gandoy, M. L. Sanjuan, E. Yus, and F. J. Dieguez. 2013. The use of crossbreeding with beef bulls in dairy herds: Effects on calving difficulty and gestation length. Animal 7:211-215. https:/ /doi.org/10.1017/S1751731112001656.

Gilmour, A. R., B. Gogel, B. Cullis, R. Thompson, and D. Butler. 2009. ASReml User Guide. Release 3.0. VSN Int. Ltd., Hemel Hempstead, UK.

Graesboll, K., C. Kirkeby, S. S. Nielsen, and L. E. Christiansen. 2015. Danish Holsteins favor bull offspring: Biased milk production as a function of fetal sex, and calving difficulty. PLoS One 10:e0124051.

Harris, B. L., and E. S. Kolver. 2001. Review of Holsteinization on intensive pastoral dairy farming in New Zealand. J. Dairy Sci. 84(E.-Suppl.):E56-E61.

Hess, M. K., A. S. Hess, and D. J. Garrick. 2016. The effect of calf gender on milk production in seasonal calving cows and its impact on genetic evaluations. PLoS One 11:e0151236. https://doi.org/10 .1371/journal.pone.0151236.

Hinde, K., A. J. Carpenter, J. S. Clay, and B. J. Bradford. 2014. Holsteins favor heifers, not bulls: Biased milk production programmed during pregnancy as a function of fetal sex. PLoS One 9:e86169. https://doi.org/10.1371/journal.pone.0086169.

Isogai, T., T. Shirai, and Y. Ikeuchi. 1994. Effects of calf breed on milk production and other economic traits of Holstein dams. Theriogenology 41:1347-1353. https://doi.org/10.1016/0093 $-691 X(94) 90493-3$.

Johnson, L. P., and L. D. Van Vleck. 1979. Components of variance associated with service sire for milk yield and reproductive traits. J. Dairy Sci. 62:754-759. https://doi.org/10.3168/jds.S0022 -0302(79)83319-6.

Judge, M. M., T. Pabiou, S. Conroy, R. Fanning, M. Kinsella, D. Aspel, A. R. Cromie, and D. P. Berry. 2019. Factors associated with the weight of individual primal cuts and their inter-relationship in 
cattle. Transl. Anim. Sci. 3:1593-1605. https://doi.org/10.1093/ tas/txz134.

Keane, M. G., and M. J. Drennan. 2008. A comparison of Friesian, Aberdeen Angus x Friesian and Belgian Blue x Friesian steers finished at pasture or indoors. Livest. Sci. 115:268-278. https://doi.org/10 .1016/j.livsci.2007.08.002.

McHugh, N., A. R. Cromie, R. D. Evans, and D. P. Berry. 2014. Validation of national genetic evaluations for maternal beef cattle traits using Irish field data. J. Anim. Sci. 92:1423-1432. https:// doi.org/10.2527/jas.2013-6658.

McHugh, N., R. D. Evans, P. R. Amer, A. G. Fahey, and D. P. Berry. 2011. Genetic parameters for cattle price and body weight from routinely collected data at livestock auctions and commercial farms. J. Anim. Sci. 89:29-39. https://doi.org/10.2527/jas.2010 -3044 .

McHugh, N., A. G. Fahey, R. D. Evans, and D. P. Berry. 2010. Factors associated with selling price of cattle at livestock marts. Animal 4:1378-1389. https://doi.org/10.1017/S1751731110000297.

Morotti, F., V. Sanches, J. H. F. Pontes, A. C. Basso, E. R. Siqueira, L. A. Lisboa, and M. M. Seneda. 2014. Pregnancy rate and birth rate of calves from a large-scale IVF program using reversesorted semen in Bos indicus, Bos indicus-taurus, and Bos taurus cattle. Theriogenology 81:696-701. https://doi.org/10.1016/j .theriogenology.2013.12.002

Moya, J., C. J. Wilcox, R. C. Littell, and W. W. Thatcher. 1989. Effects of sire of fetus upon subsequent milk production and reproduction of Jersey cows. J. Dairy Sci. 72:1012-1019. https://doi .org/10.3168/jds.S0022-0302(89)79196-7.

NRC. 2001. Nutrient Requirements of Dairy Cattle. 7th rev. ed. Natl. Acad. Sci., Washington, DC.

Pabiou, T., W. F. Fikse, P. R. Amer, A. R. Cromie, A. Nasholm, and D. P. Berry. 2011. Genetic variation in wholesome carcass cuts predicted from digital images in cattle. Animal 5:1720-1727. https: //doi.org/10.1017/S1751731111000917.

Trivers, R. L., and D. Willard. 1973. Natural selection of parental ability to vary the sex ratio of offspring. Science 179:90-92. https:// doi.org/10.1126/science.179.4068.90.

\section{ORCIDS}

D. P. Berry @ https://orcid.org/0000-0003-4349-1447

S. C. Ring (®) https://orcid.org/0000-0001-7495-4286 